BIS WORKING PAPERS

No. 69 - June 1999

\title{
CREDIT CHANNELS AND CONSUMPTION IN EUROPE:
}

EMPIRICAL EVIDENCE

by

Gabe de Bondt

BANK FOR INTERNATIONAL SETTLEMENTS

Monetary and Economic Department

Basel, Switzerland 
BIS Working Papers are written by members of the Monetary and Economic Department of the Bank for International Settlements, and from time to time by other economists, and are published by the Bank. The papers are on subjects of topical interest and are technical in character. The views expressed in them are those of their authors and not necessarily the views of the BIS.

Copies of publications are available from:

Bank for International Settlements

Information, Press \& Library Services

$\mathrm{CH}-4002$ Basel, Switzerland

Fax: +41 61 / 2809100 and +4161/2808100

This publication is available on the BIS website (www.bis.org).

(C) Bank for International Settlements 1999.

All rights reserved. Brief excerpts may be reproduced or translated provided the source is stated. 


\title{
BIS WORKING PAPERS
}

No. 69 - June 1999

\section{CREDIT CHANNELS AND CONSUMPTION IN EUROPE: EMPIRICAL EVIDENCE}

\author{
by
}

Gabe de Bondt *

\begin{abstract}
This paper studies the macroeconomic relevance of credit channels of monetary policy by examining the impact of the external finance premium (EFP), that may vary over the business cycle, on private consumption in Europe. A consumption model incorporates credit channels by assuming that liquidity-constrained consumers not only use current income for financing their consumption, but also external finance, which availability depends on the EFP. The empirical analysis shows an accelerator effect of the EFP on consumption for Germany, Italy and the Netherlands. In contrast, for France, the United Kingdom and Belgium no evidence in favour of this financial propagation mechanism has been found.
\end{abstract}

Key words: credit channels, consumption, external finance premium, EU member states.

JEL codes: C22, E21, E52.

* I am grateful to Bert Vos for data support. Valuable comments by participants of the MED-seminar at the BIS on September 29 1998, Peter van Els, Martin Fase, Gabriele Galati and Stefan Gerlach are gratefully acknowledged. The usual disclaimer applies. 


\section{Contents}

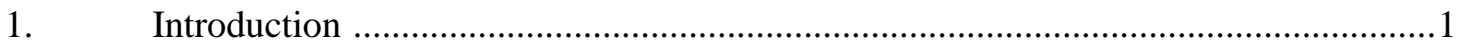

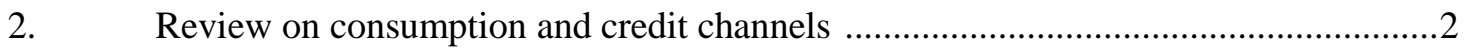

3. Modelling consumption and credit channels ….....................................................

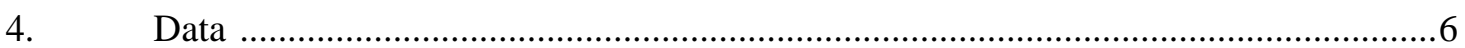

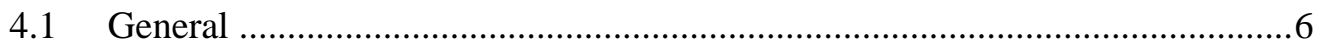

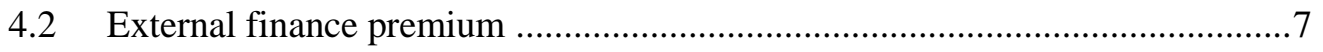

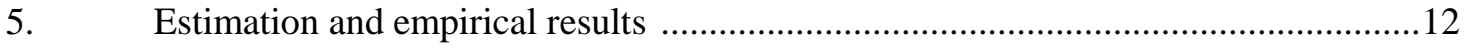

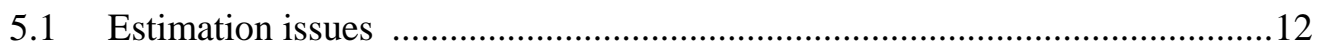

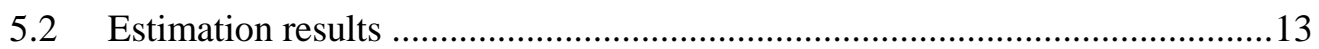

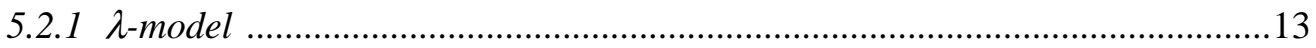

5.2.2 Modified $\lambda$-model without financial accelerator effect ................................15

5.2.3 Modified $\lambda$-model with financial accelerator effect ........................................16

$5.3 \quad$ Statistical assessment empirical results f...................................................17

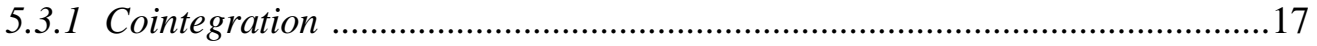

5.3.2 Other proxies to capture financial accelerator effect ….................................18

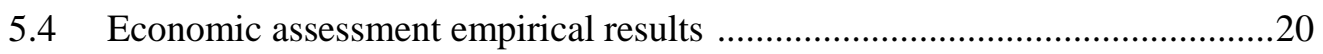

5.4.1 Intertemporal elasticity of substitution ….......................................................20

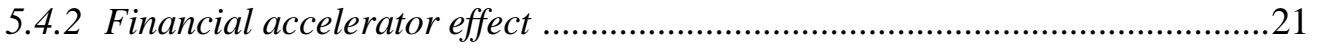

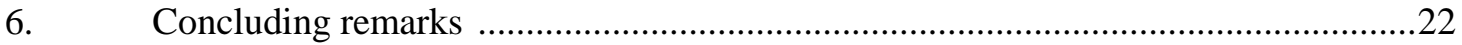

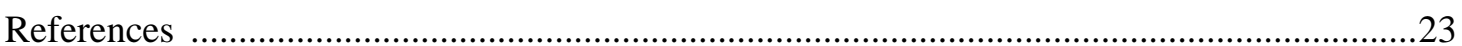




\section{Introduction}

Over the last decade, a large body of literature has examined the process of monetary transmission in general and the credit channels of monetary policy in particular (for an overview see Gertler and Gilchrist (1993), Ramey (1993), Dimsdale (1994), Bernanke and Gertler (1995) and De Bondt (1998b)). The literature on the relevance of credit channels of monetary policy in a broad sense on consumption is, however, scarce. This is surprising, because a necessary condition for the existence of a bank lending channel - the specialness of bank credit - holds for households since they lack access to other forms of credit than bank loans. Although the balance sheet channel is especially applicable to households as small borrowers, the attention paid to the role of consumers' balance sheets in monetary policy transmission is limited compared to the balance sheets of firms. In contrast, consumption has been widely studied, due to the fact that consumption expenditure accounts for more than one half of total spending and is therefore of macroeconomic relevance (for an overview see Muellbauer and Lattimore (1995)). Most empirical consumption studies document an excess sensitivity of consumption to current income, frequently interpreted as evidence of liquidity constraints, that is the inability or unwillingness to use capital markets to smooth consumption.

According to the credit channel theory the bank lending and the balance sheet channel works through a so-called external finance premium $(E F P)$, capturing the variation in credit market conditions. Costly monitoring, contract enforcement, informational asymmetries, and incentive problems between borrowers and lenders in credit markets introduce a wedge between the costs of internal and external finance. Any shock to the EFP affects a borrower's decisions, since the premium for external funds affects the overall price of funds that the borrower faces. Credit market imperfections therefore distort the real consumption decision regardless of whether there is credit rationing or not. Theory also predicts that the relevance of the bank lending channel and particularly the balance sheet channel may be asymmetric over the business cycle, known as the financial accelerator effect. Informational frictions in credit markets should be stronger, the deeper the economy is in recession and the weaker the balance sheets of households.

Against this background, this paper studies the macroeconomic relevance of credit channels of monetary policy by examining the impact of the EFP on total private consumption and investigates whether this impact varies over the business cycle.

The present paper can be seen as an extension of the literature, in that it introduces a so-called modified $\lambda$-model of consumption which incorporates the credit channels and investigates the impact of the EFP on consumption, which may vary over the business cycle along with information asymmetries between borrowers and lenders in credit markets. The model assumes that liquidity- 
constrained consumers not only use current income for financing their consumption expenditure, but also the available supply of external finance, depending on the EFP. Cross-country comparisons are employed based on an empirical analysis applied to six member states of the European Union (EU) using an identical theoretical framework. The countries considered are Germany, France, Italy, the United Kingdom, Belgium and the Netherlands. The first four are the largest European economies in terms of domestic product, while Belgium and the Netherlands are two small economies with a high degree of openness. The main empirical finding is that in Germany, Italy and the Netherlands, the impact of the EFP on consumption is propagated and amplified as the business cycle is taken into account, as predicted by the credit channel theory. During recessions this financial accelerator effect may lead to a decline in annual consumption growth of about 0.4 percentage point per quarter. In contrast, for France, the United Kingdom, and Belgium no evidence in favour of this financial propagation mechanism has been found.

The remainder of the paper is organised as follows. Section 2 reviews the literature on consumption and credit channels of monetary policy. Section 3 introduces the estimating equations by developing a consumption model, closely related to the literature, which incorporates the credit channels of monetary policy. Section 4 describes the data, in particular our proxy of the EFP. Section 5 discusses some estimation issues, presents the estimation results and assesses the empirical results from a statistical and economic point of view. Finally, Section 6 offers some concluding remarks.

\section{Review on consumption and credit channels}

Most consumption studies have focused on the Euler equation framework of optimal consumer behaviour proposed by Hall (1978). In this life cycle $(L C)$ model rational forward-looking consumers maximise expected lifetime utility, subject to intertemporal budget constraints. The resulting model equation implies, assuming that the real interest rate is constant or the intertemporal elasticity of substitution is zero, that changes in consumption should not be predictable. The same result is derived from a permanent income $(P I)$ framework where revisions to the planned consumption path arise from news about future income, which by definition is unpredictable. Empirical research has shown, however, that some variables have enough predictive power to reject the random walk hypothesis of the $L C$ and PI theory (see, among many others, Antzoulatos (1994, 1995 and 1997)). Some authors provide a cross-country comparison of the excess sensitivity of consumption to current income, trying to attribute it to liquidity constraints (Jappelli and Pagano (1989) and Campbell and Mankiw (1991)), while others examine the time variation in excess sensitivity (Bayoumi (1993), Bacchetta and Gerlach (1997) and Sarno and Taylor (1998)) or explore the asymmetric behaviour of excess sensitivity (Blundell-Wignall et al. (1995) and Shea (1995)). 
The present study takes a different approach, by taking credit channels of monetary policy into account. We examine the relation between consumption and the $E F P$, which plays a crucial role in the credit channel theory (see among many others, Bernanke and Gertler (1995) and De Bondt (1998b)). The EFP forms a potential underlying source of liquidity constraint, since it reflects the costs due to capital market imperfections. Two mechanisms explain the link between monetary policy and the EFP: the bank lending and the balance sheet channel.

According to the bank lending channel a contraction of monetary policy drains deposits from the banking system, which forces banks to readjust their portfolio by reducing their supply of loans, given the imperfect substitutability between loans and other assets. This reduction in the supply of bank loans relative to other forms of credit is likely to increase the EFP. In other words, an increase in the cost of funds to banks should shift the supply of loans inward, squeezing out bank-dependent borrowers and raising the EFP. The idea of the balance sheet channel is that the EFP depends inversely on a borrower's creditworthiness, which in turn depends primarily on macroeconomic conditions and therefore on monetary policy. For example, a monetary policy tightening deteriorates net worth by a fall in asset prices or by a rise in the burden of debt through an unanticipated fall in the price level. The credit channel theory holds that capital market imperfections may act as an essential factor of propagation and amplification of an initial monetary policy shock, known as the financial accelerator effect. This financial propagation mechanism varies over the business cycle along with information asymmetries between borrowers and lenders in credit markets. Credit constraints are likely to be binding across a wider group of consumers in recessions than in booms. In periods of expansion, informational asymmetries are relatively moderate. In this paper the financial accelerator effect is taken into account by examining the EFP in conjunction with the business cycle.

Several consumption studies have already investigated a borrowing-lending wedge, possibly a proxy for the EFP, but they do not examine whether the impact of this wedge depends on economic activity. King (1986) introduces a model in which information asymmetries between borrowers and lenders lead to an endogenously determined wedge between borrowing and lending rates. He finds a significant impact of the EFP on British consumption. A cross-country analysis by Jappelli and Pagano (1989), which looks at Italy and the United Kingdom, shows no relationship between the estimated excess sensitivity of consumption to current income and the EFP. Finally, Bacchetta and Gerlach (1997) examine the EFP of five countries, including France and the United Kingdom. For these two countries they find that the EFP does not help to predict consumption changes. 


\section{Modelling consumption and credit channels}

We assume a representative agent with a time horizon of $T$ future periods who maximises the following objective function

$$
V_{0}=E_{0} \Sigma_{t}(1+\rho)^{-t} U\left(C_{t}\right), t=0, \ldots, T
$$

subject to the wealth constraint

$$
A_{t+1}=\left(1+r_{t}\right)\left(A_{t}+Y^{\alpha}{ }_{t}-C_{t}\right), t=0, \ldots, T
$$

where $U(\bullet)$ is the single-period utility function, $C_{t}$ is real per capita consumption at time $t, \rho$ is the individual rate of time preference, and $E_{t}$ the expectation operator conditional on information at time $t$. We assume strict concavity and double differentiability of the utility function. $A_{t}$ represents net real assets at the beginning of period $t, Y^{\alpha}{ }_{t}$ is real labour income during time $t$ and $r_{t}$ is the real rate of interest at which the representative consumer can borrow or lend from the beginning of period $t$ to the beginning of period $t+1$. The first-order conditions for the maximisation of equation (1) subject to equation (2) are equal to a set of Euler equations

$$
1=E_{t}\left[(1+\rho)^{-1}\left(1+r_{t}\right) U^{\prime}\left(C_{t+1}\right) / U^{\prime}\left(C_{t}\right)\right]
$$

Assuming an isoelastic utility function of the form $U\left(C_{t}\right)=\sigma(\sigma-1)^{-1} C_{t}^{(\sigma-1) / \sigma}$, where $\sigma$ is the intertemporal elasticity of substitution, and $\ln C_{t}$, denoted by $c_{t}$, and $r_{t}$ are jointly normally distributed the Euler equation simplifies to

$$
E_{t} \Delta c_{t+1}=\sigma\left(E_{t} r_{t}-\rho\right)+\sigma^{-1} \omega_{t+1}^{2} / 2
$$

with

$$
\omega_{t+1}^{2}=\operatorname{Var}_{t}\left(\Delta c_{t+1}-\sigma r_{t}\right)
$$

where $\operatorname{Var}(\bullet)$ denotes conditional variance. Assuming that this conditional variance is constant and lagging equation (4) gives

$$
E_{t-1} \Delta c_{t}=\mu^{*}+\sigma E_{t-1} r_{t-1}
$$

where $\mu^{*}$ is a constant. ${ }^{1}$ An increase in the real interest rate in period $t-1, r_{t-1}$, reduce consumption in period $t-1$ relative to that of current consumption. How much is transferred to the present depends directly on the magnitude of the intertemporal elasticity of substitution $(\sigma>0)$. If the real interest rate is constant or the intertemporal substitution elasticity is zero, then equation (6) shows that consumption just follows a random walk with drift.

\footnotetext{
In fact $\mu *$ is not constant because it includes the conditional variance. We test for autoregressive conditional heteroscedasticity $(A R C H)$ effects in the residual series for the estimated models and discover only in two cases significant $A R C H$ effects, implying that treating this conditional variance term as constant is justified.
} 
The literature argues that if a significant proportion of consumers is unable to smooth consumption because of liquidity constraints, movements in current income may be an additional explanatory factor of consumption. We distinguish two groups of consumers, as suggested by the "Keynesian" rule-ofthumb model of Campbell and Mankiw (1990 and 1991). One group consists of liquidity-constrained consumers for which consumption expenditure is a constant fraction, $\lambda$, of income, the other group, $(1-\lambda)$, is assumed to behave according to equation (6). This $\lambda$-model replaces equation (6) by

$$
E_{t-1} \Delta c_{t}=(1-\lambda)\left[\mu^{*}+\sigma E_{t-1} r_{t-1}\right]+\lambda E_{t-1} \Delta y_{t}
$$

where $y$ is the natural logarithm of per capita real disposable income. Parameter $\lambda$ denotes the fraction of rule of thumb consumers and $(1-\lambda)$ denotes the fraction of PI consumers. One cannot rule out that the excess sensitivity of consumption to current income derives from the failure of other assumptions of the $L C$ theory, such as the consumers' ability to make rational forecasts of future income. For example, Winder and Palm (1989) show that the sensitivity to current income is related to a finite planning time horizon.

Of the assumptions underlying the $L C$ and $P I$ hypotheses, the postulate of perfect credit markets has typically been seen as the source of the empirical failure of the theory. If a consumer cannot borrow and lend freely at some stage his desired consumption will probably be constrained by current resources, such as disposable income and the available supply of external finance. We now assume there are two groups of liquidity-constrained consumers. One is assumed to consume a constant fraction, $\lambda_{1}$, of current income and the other group a constant fraction, $\lambda_{2}$, of both current income and the available supply of external finance. In turn, shifts in the availability of external finance supply are assumed to depend on the change in the EFP one period lagged or one period lagged change in the $E F P$, because it takes some time to obtain the external finance sources for consumption expenditure after a change in the EFP. In addition, the impact of the EFP on credit supply varies over the business cycle along with credit market imperfections. The liquidity-unconstrained group is still the PI group, $\left(1-\lambda_{1}-\lambda_{2}\right)$. This leads to a modified $\lambda$-model with financial accelerator effect equal to

$$
E_{t-1} \Delta c_{t}=\left(1-\lambda_{1}-\lambda_{2}\right)\left[\mu^{*}+\sigma E_{t-1} r_{t-1}\right]+\lambda_{1}\left[E_{t-1} \Delta y_{\mathrm{t}}\right]+\lambda_{2}\left[E_{t-1} \Delta y_{t}+E_{t-1} \Delta \text { credit supply }{ }_{t}\right]
$$

with

$$
\Delta \text { credit supply } y_{t}=\alpha_{0}+\alpha_{1} \Delta E F P_{t-1}+\alpha_{2} \Delta E F P_{t-1} \bullet b c_{t-1}
$$

or equivalently

$$
\Delta c_{t}=\mu+\theta r_{t-1}+\left(\lambda_{1}+\lambda_{2}\right) \Delta y_{t}+\alpha_{1}^{\prime} \Delta E F P_{t-1}+\alpha_{2}{ }^{\prime} \Delta E F P_{t-1} \bullet b c_{t-1}+\varepsilon_{t}
$$

where $b c_{t}$ denotes the business cycle in period $t, \mu=\left(1-\lambda_{1}-\lambda_{2}\right) \mu *+\lambda_{2} \alpha_{0}, \theta=\left(1-\lambda_{1}-\lambda_{2}\right) \sigma, \alpha_{1}{ }^{\prime}=\lambda_{2} \alpha_{1}$, $\alpha_{2}{ }^{\prime}=\lambda_{2} \alpha_{2}$ and the error term, $\varepsilon_{t}$, is orthogonal to all variables known at time $t-1$ or earlier. 
Based on equation (10) three consumption models are estimated. First, we estimate the $\lambda$-model, assuming in equation (10) $\lambda_{2}=0$, that is liquidity-constrained consumers use only current income. The second estimated model is a modified $\lambda$-model without financial accelerator effect, that is the impact of the EFP does not vary over the business cycle $\left(\alpha_{2}=0\right)$. The third and last model is the modified $\lambda$-model with financial accelerator effect with no parameter restrictions.

\section{Data}

\subsection{General}

The sample period starts with the first quarter in 1980 and ends with the last quarter of 1995. It ends two years before the latest available observations to avoid problems arising from later data revisions. This period is particularly interesting to examine, because it is often argued that financial deregulation has relaxed liquidity constraints, particularly in the 1980s. In addition, the impact of derivatives on the real economy has changed dramatically over the last decade (Vrolijk (1997)). The bank lending channel can be reduced through financial innovation and by alternative funding. The balance sheet channel may also have become weaker, since more net worth changes can be hedged. On the other hand, households nowadays perhaps face earlier a change in borrowing costs.

All data except the interest rates used to construct the EFP, are taken from the database of the macroeconomic model for the EU of De Nederlandsche Bank (De Bondt et al. (1997)). German data show a structural break in 1991 because of German unification. We examine total private consumption expenditure instead of consumption of nondurable goods and services, strictly speaking the appropriate notion in the LC theory, since time series of nondurables and services are not available for Germany, Italy and Belgium. ${ }^{2}$ Analysing total private consumption expenditure has the advantage that it is of greater importance in gross domestic product and in this way is more representative for possible macroeconomic effects of the credit channels of monetary policy. Disposable income is the sum of wage, transfer and other income, mostly consisting of financial income, minus tax and social security. If only annual figures are available, in the case of national accounts data for Belgium, then these figures are transformed to quarterly frequency by the Ginsburgh method. Annual population figures are transformed to quarterly frequency by the Lismann method. Consumption and income has been rendered real by using the price deflator of private consumption. Per capita figures are

2 The modelling of consumption does not change, because the theory of durable consumption is not really different from the theory of nondurable consumption. Mankiw (1982) notes that the maximisation problem of consumption including durable goods is formally similar to Hall's framework for nondurable consumption, with the addition of an $M A(1)$ process. If the deterioration of the stock of durables occurs at a constant rate, the purchases of durables obeys a first order moving average process, where the moving average parameter depends only on the rate of depreciation of the stock of durables. 
constructed by dividing by total population. The relevant nominal interest rate is assumed to be a weighted average of the short and long-term interest rate, where the fixed weights depend on the credit maturity structure of households as reported in De Bondt (1998a); a weight of the short-term interest rate of $40 \%$ for Italy, $20 \%$ for the United Kingdom and 10\% for the other countries. ${ }^{3}$ For the expected inflation component of the real interest rate we use the actual change in the price deflator of private consumption. Business cycle indicators, as constructed by De Nederlandsche Bank, measure the cyclical position (Berk and Bikker (1995)). These indicators are based on an improved variant of the NBER method (Fase and Bikker (1985) and Bikker and De Haan (1988)) yielding a composite leading indicator characterised by smooth movements and clear turning points.

\subsection{External finance premium}

Any empirical measure of the $E F P$ will necessarily be subject to measurement error, because few data are available on the external and internal finance rate for consumers. A mortgage or similar interest rate is our proxy for the cost of external finance, since this interest rate is expected to be related to the net worth of consumers (balance sheet channel) and owner-occupied housing wealth is the most important single asset of households.

Table 1 shows the sample mean of the outstanding stock of housing mortgage loans, personal consumer loans and their sum, scaled by annual consumption. Housing mortgage loans clearly form the largest component of outstanding stock of consumer debt. A striking cross-country difference is the large outstanding stock of consumer debt in Germany and small stock of debt in Italy, both housing mortgages as personal consumer loans. The differences between the other countries are relatively minor. The ratios for Italy and the United Kingdom are almost the same as reported by Jappelli and Pagano (1989) for the period 1961-85 and 1961-83, respectively. Jappelli and Pagano report debt-consumption ratios of 7.8 and 2.1 for Italy, against 7.0 and 2.8 for the period 1980-95. These numbers are for the United Kingdom 46.4 and 9.9, against 47.5 and 7.6. This is surprising, since one expects that financial liberalisation improved the access to credit, particularly in Italy. It is unlikely the small debt-consumption ratios for Italy are due to permanent severe liquidity constraints. It is more likely that the comparatively high level of interest rate in Italy makes consumers borrow less than in other countries. In Italy the sample mean of the external finance rate is $15 \%$, at least $3 \%$ higher than in the other countries and even $6 \%$ higher than in Germany.

Although housing mortgage loans are generally collateralised and often subject to different tax regimes relative to personal consumer loans, the distinction between the two markets should not be

The estimation results in the next sections rarely change as the long-term interest rate is used instead of the weighted interest rate. This is not surprising, because of the large weight of the long-term interest rate. The only exception is Italy, where interest rate effects are most significant with a weight of $100 \%$ for the short-term interest rate. 
overrated. There is evidence that consumers tend to arbitrage between mortgages and personal consumer loans, often obtaining credit more cheaply in the market for mortgages in order to finance current consumption rather than the purchase of a house (Jappelli and Pagano (1989)). For this reason our proxy of the EFP perhaps underestimates the true EFP. On the other hand, the tax deductibility of the interest rate is not taken into account; a potential source of overestimating the true $E F P{ }^{4}$

Table 1

Consumer debt market, 1980 - 95 (as a percentage of consumption)

\begin{tabular}{l|c|c|c|c|c|c}
\hline & Germany & France & Italy & $\begin{array}{c}\text { United } \\
\text { Kingdom }\end{array}$ & Belgium & Netherlands \\
\hline Housing mortgage loans & 55.6 & 40.5 & 7.0 & 47.5 & 31.8 & 39.5 \\
Personal consumer loans & 16.4 & 5.8 & 2.8 & 7.6 & 6.6 & 3.9 \\
Total consumer debt & 72.0 & 46.3 & 9.8 & 55.1 & 38.4 & 43.4 \\
\hline
\end{tabular}

Sources: BIS and De Nederlandsche Bank.

For the internal cost of finance a saving deposit or similar rate is used. Because of differences in definitions of the interest rates used, the differences in the mean and standard deviation of the EFP should be regarded as approximate measures of the actual differences in the EFP (see Table 2). Based on these definitions the most precise measure of the EFP seems to be for the United Kingdom and Belgium, where both finance rates are available for the same type of institution, namely building societies and general savings and pension funds (Caisse Générale d'Épargne et de Retraite, abbreviated as CGER), respectively. The mean of the EFP varies between $4.6 \%$ in Italy and $6.1 \%$ in Belgium and the standard deviation is $1 \%$ in Germany and the Netherlands and about $1.5 \%$ in the other countries.

Table 2

Proxies external finance premium, 1980 - 95

\begin{tabular}{|c|c|c|c|c|}
\hline \multirow{2}{*}{ Country } & \multicolumn{2}{|c|}{ EFP } & \multicolumn{2}{|r|}{ Definitions } \\
\hline & Mean & $\begin{array}{l}\text { Standard } \\
\text { deviation }\end{array}$ & External finance rate & Internal finance rate \\
\hline Germany & 0.055 & 0.010 & Mortgages variable rate & Savings deposits with legal period of notice \\
\hline France & 0.050 & 0.013 & Housing credit (min) & Bank accounts on passbooks \\
\hline Italy & 0.046 & 0.015 & Bank credits & Savings deposits with banks \\
\hline $\begin{array}{l}\text { United } \\
\text { Kingdom }\end{array}$ & 0.057 & 0.015 & $\begin{array}{l}\text { Building society mortgage } \\
\text { loans (nominal rate) }\end{array}$ & $\begin{array}{l}\text { Building society shares (rates paid to } \\
\text { lenders) }\end{array}$ \\
\hline Belgium & 0.061 & 0.017 & Mortgage loans by the CGER & $\begin{array}{l}\text { Deposits in ordinary savings banks books } \\
\text { with the CGER }\end{array}$ \\
\hline Netherlands & 0.050 & 0.011 & Mortgage loans (nominal rate) & Time savings deposits (3 months) \\
\hline
\end{tabular}

Source: OECD Financial Statistics.

On balance, we assume that measurement errors do not affect our parameter estimates. An approach to deal with the measurement problem of the cost of external finance, not followed here, is to observe the bank lending rate as a zone rather than as a unique and directly measurable market price (Fase (1995)). 
Figure 1 plots the EFP in all countries. Broadly speaking, the countries can be split into three groups. The first group consists of Germany, Belgium and the Netherlands, where the EFP at the end of the sample period is almost equal to the value at the start. In between, the EFP is relatively high in the early 1980s and 1990s. The former period is characterised as a period of recession, while the last period is dominated by the German unification, which induced relatively tight credit market conditions. Secondly, the EFP of the United Kingdom is also at the end of the sample period almost equal to 1980. Between 1985 and 1991, however, the EFP is high compared to the first group of countries. For the years 1989 to 1991 the high EFP may be explained by a strong decline in real economic growth, about 2 percentage points per year. The third and last group consists of France and Italy. In both countries the EFP has declined over the sample period and the development in the EFP differs in particular since 1990 compared to the first group of countries. A possible explanation of this decline is that France and especially Italy were subject to relatively high financial regulation in the 1980s, causing a gradual decline in the EFP in the 1990s (De Bondt (1998a)).

Figure 1

\section{External finance premium}

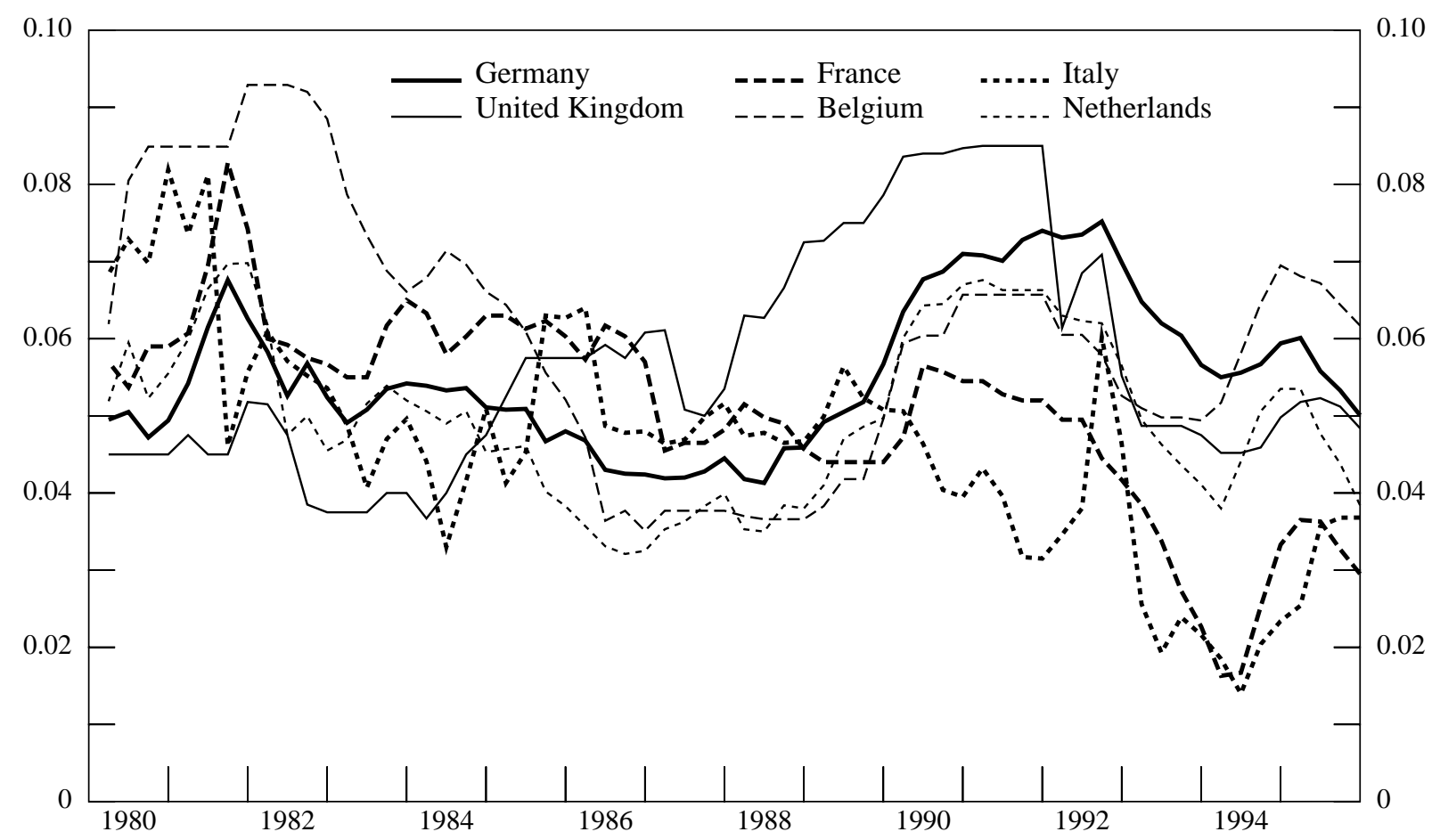

To assess the relation between monetary policy and our proxy of the EFP we estimate a VAR system with 4 lags that includes the short-term interest rate and the EFP, in that order. ${ }^{5}$ Figure 2 shows the estimated dynamic responses of the short-term interest rate and the EFP to a positive one-standard-

5 Other studies examining more or less the EFP in a VAR model with more than two-variables are e.g. Davis and Henry (1994), Tsatsaronis (1995), Barrán (1996) and Kroes (1996). 
Figure 2

\section{Impulse response functions due to monetary policy shock}

Short-term interest rate

Asymptotic response errors

Germany

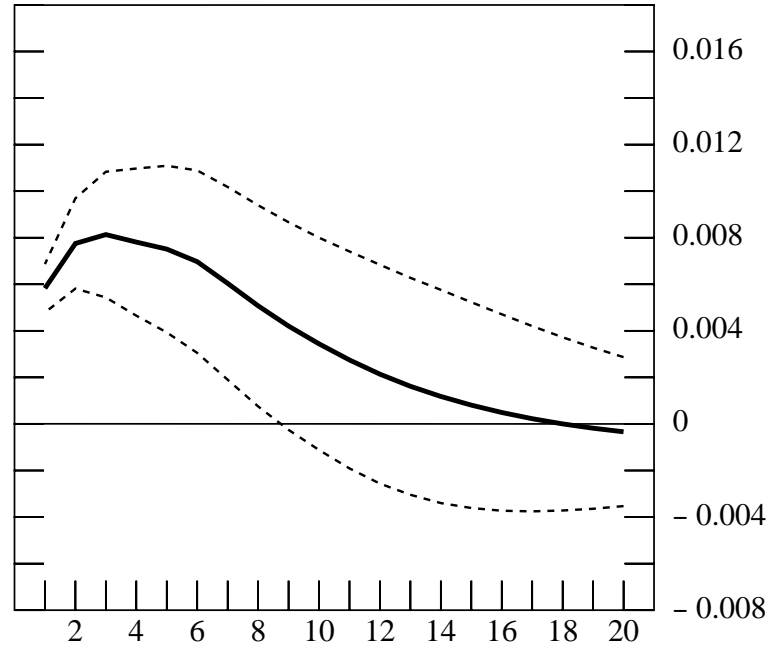

France

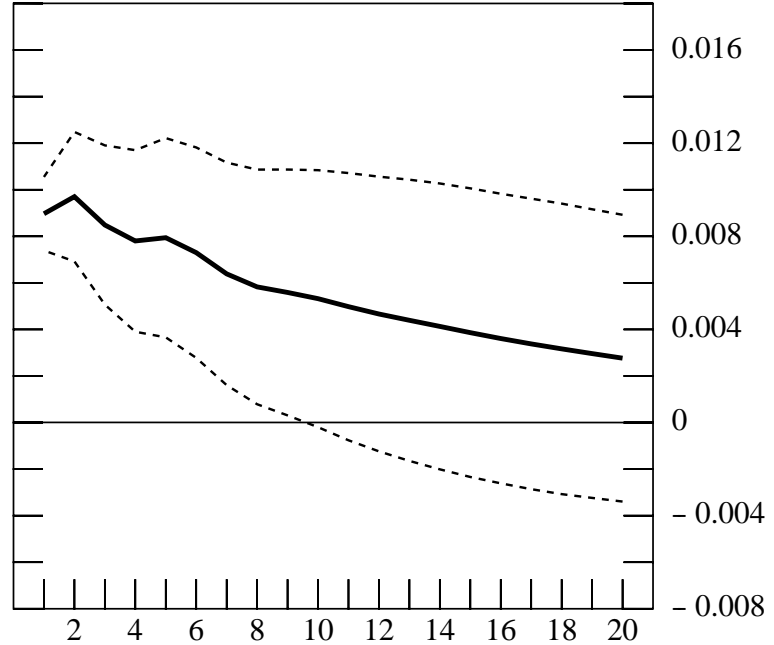

Italy

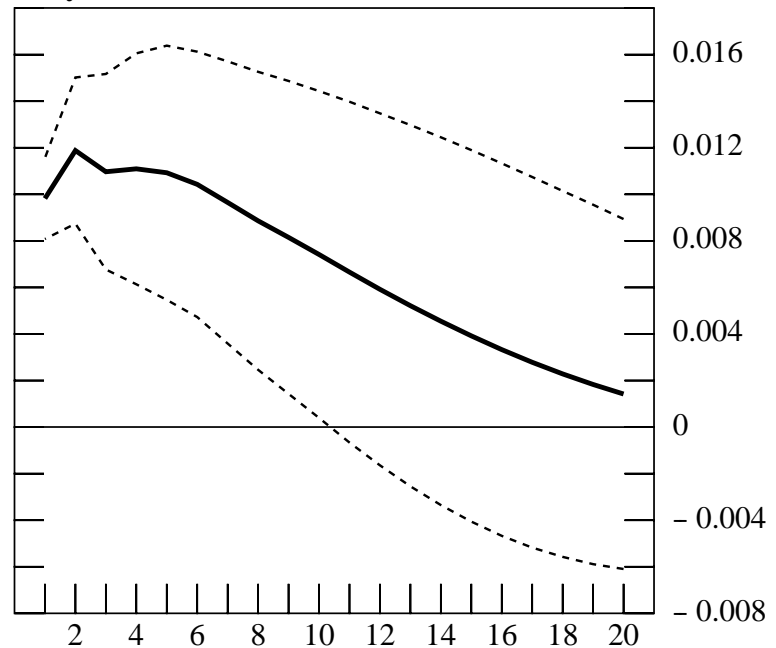

External finance premium

Asymptotic response errors
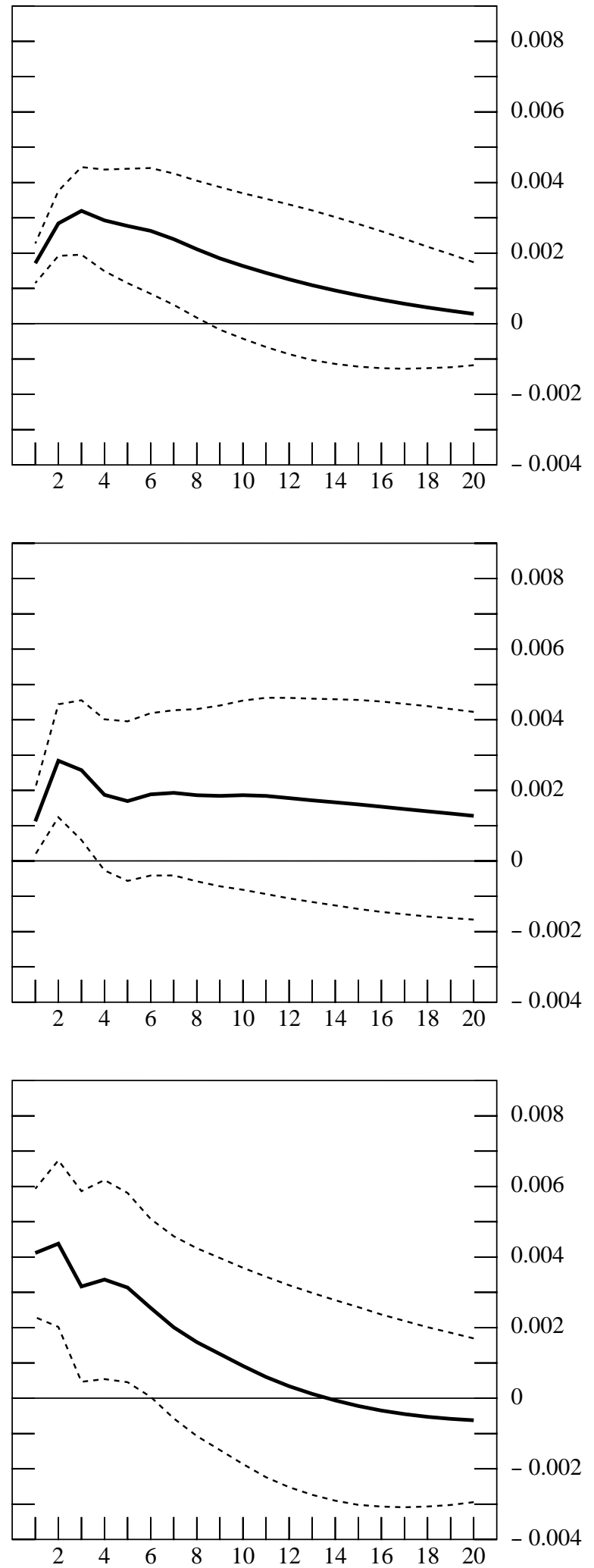
Figure 2 (cont.)

Short-term interest rate
. A Asymptotic response errors

United Kingdom

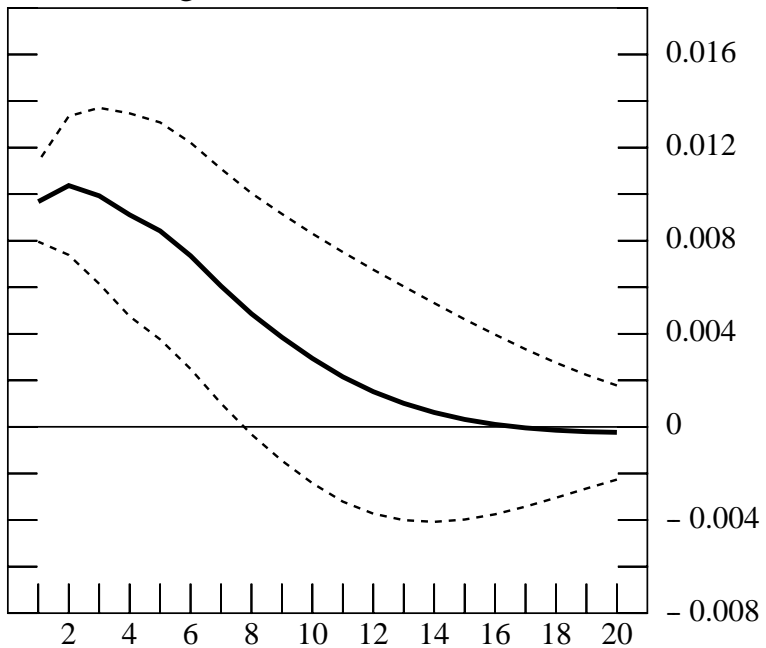

Belgium

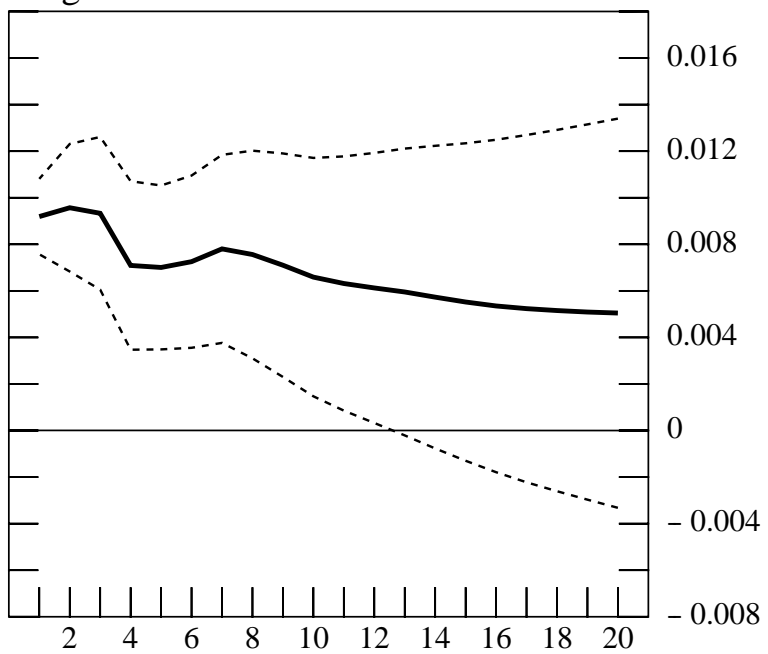

Netherlands

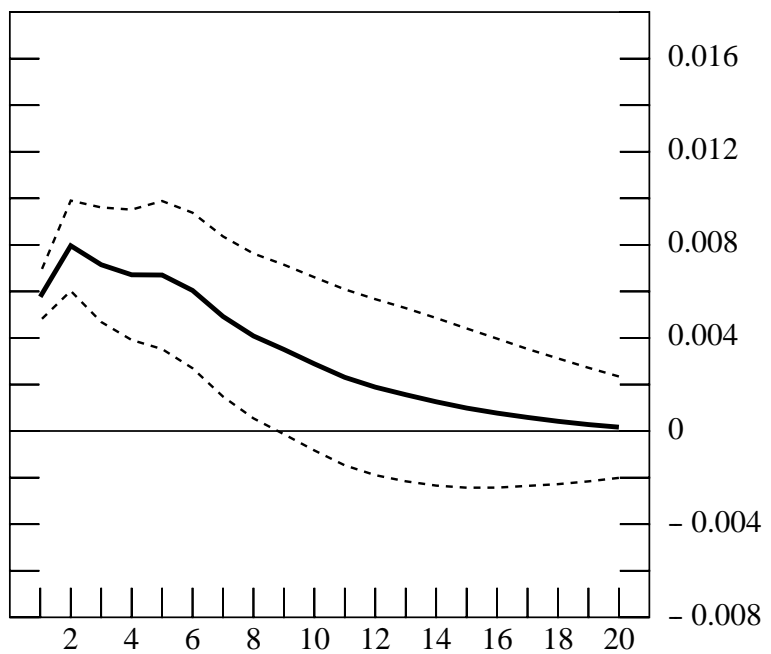

External finance premium

Asymptotic response errors
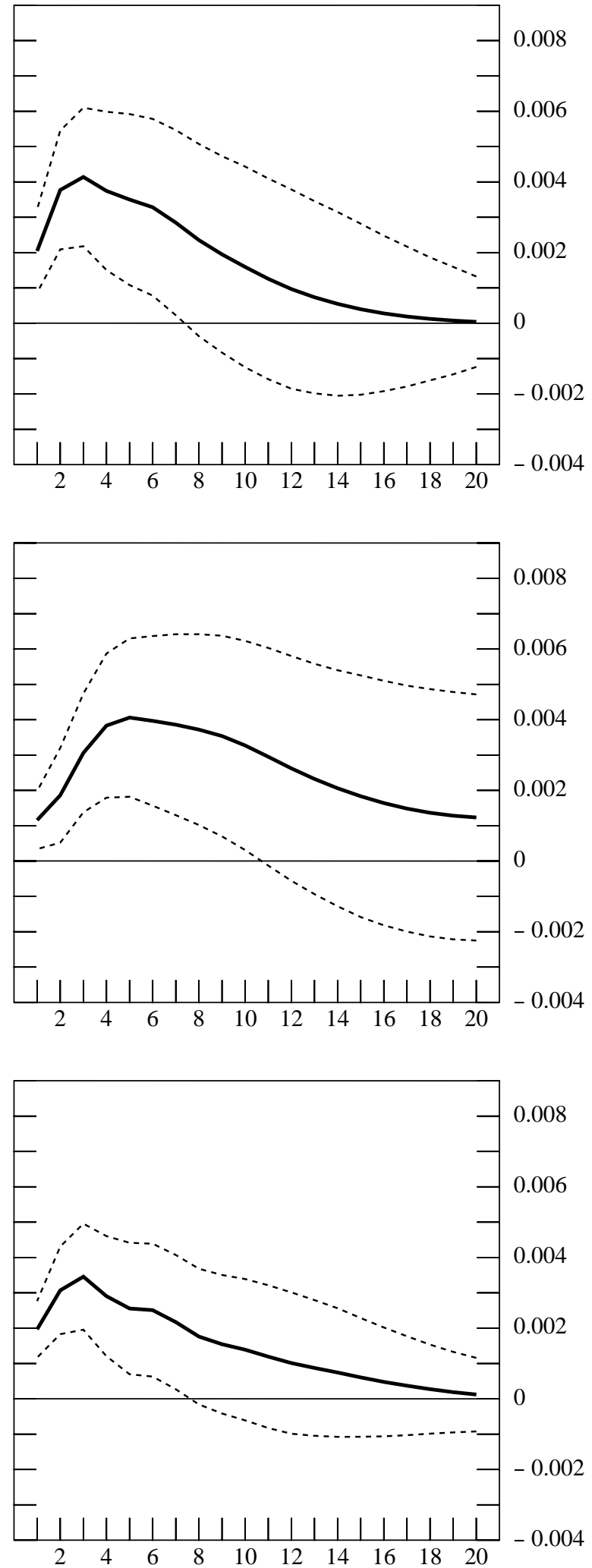
deviation shock to the short-term interest rate, interpreted as a monetary policy tightening. The EFP increases and reaches a peak after two or three quarters, bottoming out afterwards just like the movements of the short-term interest rate. Only in Belgium the EFP reacts more slowly to a monetary policy shock, reaching its peak after five quarters. The highest rise in the EFP after a one-standarddeviation shock to the short-term interest rate amounts 30 to 40 basis points. In France the EFP significantly rise only in the first three quarters, while the other countries show a significant increase in the EFP in the first six quarters. Overall, the impulse responses clearly show that the EFP significantly increases after a monetary policy tightening, as expected by the credit channel theory.

\section{Estimation and empirical results}

After a discussion of estimation issues (Section 5.1), Section 5.2 presents the estimation results. The next sections assess the empirical results from a statistical (5.3) and economic (5.4) point of view.

\subsection{Estimation issues}

Since the variables in the model equations represent expected values, it is necessary to estimate the model using instrumental variables (IV) techniques. Our instruments, based on other studies, are: the consumption income ratio lagged four periods, the second and third lags of dependent and all independent variables, the fourth difference of the term spread and the first difference of the inflation rate. Inflation is defined as the four-quarter growth rate in the consumption price deflator. The change in the spread and the change of inflation are also appealing instruments, since there is considerable evidence that both variables help to forecast changes in income. The instruments are lagged more than one period so that there is at least a two-period time gap between instruments and explanatory variables, and the residuals are assumed to follow a $M A(1)$ process. Lagged variables are only valid instruments if they are stationary. Preliminary unit root tests indicate that the model variables and instruments are all apparently $I(0)$. For some countries, additional $A R$ or $M A$ terms are included based on the autocorrelations and partial correlations of the residuals.

There are several reasons for the extra lags in the instruments and the assumed $M A(1)$ structure of the residuals (Campbell and Mankiw (1990 and 1991)). First, modelling consumption of durable goods can lead to an $M A(1)$ error structure, in which the moving average parameter is related to the rate of depreciation of durable goods (Mankiw (1982)). One obtains consistent estimates by lagging the instruments twice. Secondly, the $M A(1)$ structure and twice-lagged instruments take into account possible white noise measurement error in the levels of the EFP and other model variables. Thirdly, the underlying consumption model applies to variables measured at points in time, whereas available data are time-averaged, which can produce spurious first-order auto and crosscorrelations. Finally, 
lagging the instruments two quarters mitigate the problem of delays in the publication of model variables. Appropriate instruments should be correlated with the explanatory variables and uncorrelated with the error-term. The next tables, therefore, report the adjusted $\mathrm{R}^{2}$ from OLS first stage regression of the independent model variables on the instruments and of the regression of the IV-residuals (IV-res) on the instruments. The tables also contain the p-value of a Wald test of the null hypothesis that all coefficients with respect to the instruments in the regression are jointly zero. Moreover, the p-value from a Lagrange Multiplier $(L M)$ test of the over-identifying restrictions of the model is given. The statistic is computed by multiplying the $\mathrm{R}^{2}$ from the regression of the IV-residuals on the instruments with the sample size of 64 and is chi-squared distributed with the number of degrees of freedom equal to the number of over-identifying restrictions.

It is essential to treat seasonally unadjusted data in such a way that seasonal factors do not drive our results. One possibility is to regress the data on seasonal dummies, but we found that this does not adequately remove seasonal pattern. For example, in the Netherlands and Italy the seasonal variation has changed during the sample period. Therefore we use annual growth rates and include quarterly dummies for the years where the seasonal pattern has changed in Italy and the Netherlands. This procedure is conservative in that it minimises the probability that the random walk hypothesis of the $L C$ and $P I$ theory can be rejected by inappropriate handling of seasonality. It also reduces the power of our tests, because annual growth rates (fourth difference) are harder to forecast than near-term quarterly growth rates (first difference).

\subsection{Estimation results}

\subsection{1 $\lambda$-model}

Table 3 contains the estimation results of the $\lambda$-model. In the United Kingdom and Belgium, income growth contributes significantly to consumption growth and in the Netherlands the real interest rate. ${ }^{6}$ In the United Kingdom and Belgium the excess sensitivity of consumption to current income is so strong that the PI model has to be rejected in favour of the $\lambda$-model. In the other countries consumers do not appear to be liquidity constrained. The relative low $\mathrm{R}^{2}$ for Belgium is due to the poor quality of the Belgian data, since for Belgium only annual national account figures are available. In all countries except Italy and the United Kingdom the instruments used are appropriate, since they explain the real interest rate and income growth and are uncorrelated with the IV-residuals.

6 Throughout the paper significant refers to a significance level of 5\%, unless stated otherwise. 
Table 3

$\lambda$-model

\begin{tabular}{|c|c|c|c|c|c|c|}
\hline & Germany & France & Italy & $\begin{array}{c}\text { United } \\
\text { Kingdom }\end{array}$ & Belgium & Netherlands \\
\hline \multirow[t]{2}{*}{$r_{-1}$} & $0.345 *$ & 0.021 & -0.012 & 0.192 & 0.467 & $1.192 * * *$ \\
\hline & $(1.85)$ & $(0.15)$ & $(0.10)$ & (1.09) & $(1.34)$ & $(3.35)$ \\
\hline \multirow[t]{2}{*}{$\Delta_{4} y$} & 0.084 & 0.163 & $0.234 *$ & $0.115^{* * *}$ & $0.396 * * *$ & -0.152 \\
\hline & $(0.75)$ & $(1.21)$ & (1.89) & $(2.84)$ & $(4.96)$ & $(0.77)$ \\
\hline $\mathrm{R}^{2}$ & 0.740 & 0.644 & 0.952 & 0.832 & 0.367 & 0.565 \\
\hline $\mathrm{R}^{2}$ (adjusted) & 0.707 & 0.614 & 0.945 & 0.818 & 0.324 & 0.463 \\
\hline SE of regression & 0.013 & 0.007 & 0.006 & 0.012 & 0.017 & 0.014 \\
\hline \multicolumn{7}{|l|}{ Wald test, p-value } \\
\hline$H_{0}: P I$ model & 0.457 & 0.231 & $0.064 *$ & $0.006^{* * *}$ & $0.000 * * *$ & 0.446 \\
\hline \multicolumn{7}{|l|}{ Validity instruments } \\
\hline $\mathrm{R}^{2}$ (adjusted) $r_{-1}$ & 0.589 & 0.851 & 0.905 & 0.885 & 0.516 & 0.615 \\
\hline Wald test, $p$-value & $0.000 * *$ & $0.000^{* * *}$ & $0.000^{* * *}$ & $0.000^{* * *}$ & $0.000^{* * *}$ & $0.000^{* * *}$ \\
\hline $\mathrm{R}^{2}$ (adjusted) $\Delta_{4} y$ & 0.615 & 0.591 & 0.906 & 0.750 & 0.488 & 0.727 \\
\hline Wald test, $p$-value & $0.000 * *$ & $0.000 * * *$ & $0.000 * * *$ & $0.000^{* * *}$ & $0.000 * * *$ & $0.000 * * *$ \\
\hline $\mathrm{R}^{2}$ (adjusted) IV-res & 0.017 & 0.053 & 0.191 & 0.265 & 0.035 & -0.161 \\
\hline Wald test, $p$-value & 0.405 & 0.241 & $0.036 * *$ & $0.003 * * *$ & 0.307 & 0.917 \\
\hline$L M$ test, $p$-value & $0.066 *$ & 0.124 & $0.003 * * *$ & $0.003^{* * *}$ & 0.163 & 0.150 \\
\hline
\end{tabular}

Explanatory notes: IV estimates of $\Delta_{4} c_{t}=\mu+\lambda_{1} \Delta_{4} y_{t}+0 r_{t-1}+\varepsilon_{t}$, based on equation (10) with $\lambda_{2}=0$; ***, ** and * denote significance at the $1 \%, 5 \%$ and $10 \%$ level, respectively; absolute Newey-West heteroscedasticity and autocorrelation corrected $t$-statistics between parentheses; $M A(1)$ errors assumed; additional $A R$ or $M A$ terms included based on autocorrelations and partial correlations and dummies because of structural (seasonal) break; instruments are consumption income ratio lagged four periods, lags two to three of dependent and independent variables, fourth difference of spread, and first difference of inflation; $p$-value below $\mathrm{R}^{2}$ (adjusted) is the $p$-value of a Wald test that all coefficients with respect to the instruments are jointly zero; $p$-value $L M$ test indicates the validity of the over-identifying restrictions.

Other cross-country studies document significant excess sensitivity parameters of about 0.5 for Italy and the United Kingdom (Jappelli and Pagano (1989)), of 0.4 and 0.7 for France and the United Kingdom, respectively (Campbell and Mankiw (1991)) and of around 0.2 for France and the United Kingdom (Bacchetta and Gerlach (1997)). Blundell-Wignall et al. (1995) find for Germany a significant excess sensitivity parameter of 1.04 for the 1980s/90s. They present, however, for France, Italy and the United Kingdom insignificant $\lambda$-values for the 1980s/90s, compared with significant values in earlier periods. They contribute this to an easing of liquidity constraints by financial liberalisation. Overall, our estimated $\lambda$-values are low compared to the literature, probably due to a recent sample period.

Jappelli and Pagano (1989) suggest that the departure from the predictions of the LC and PI theory would be larger in countries with more imperfect capital markets than in countries where they are well developed and highly competitive. This does not appear to be the case; Italy is one of the countries with no significant excess sensitivity of consumption to current income, while it has one of the least developed capital markets of the countries considered. At the other side of the spectrum is the United Kingdom, which shows a significant excess sensitivity of consumption to current income. 


\subsubsection{Modified $\lambda$-model without financial accelerator effect}

Table 4 presents the estimation results of the consumption model, which incorporates the credit channels of monetary policy without taking into account the possibility of a financial propagation mechanism. Real interest rate movements significantly explain consumption in Germany and the Netherlands. In most countries $80 \%$ to $100 \%$ of all consumers are liquidity unconstrained. The exceptions are the United Kingdom and Belgium, where in view of our results about $50 \%$ of the consumers are liquidity constrained. In all countries excluding Germany, the impact of the EFP is not significantly different from zero. In Germany a rise in the EFP by 1 percentage point leads to a $0.7 \%$ decrease in consumption. It is obvious that only for Germany the $\lambda$-model has to be rejected in favour of the modified $\lambda$-model without financial accelerator effect. In all countries the IV-residuals are now uncorrelated with the instruments. The $L M$ test, however, indicates that the over-identifying restrictions are rejected for Germany and Italy.

Table 4

Modified $\lambda$-model without financial accelerator effect

\begin{tabular}{|c|c|c|c|c|c|c|}
\hline & Germany & France & Italy & $\begin{array}{c}\text { United } \\
\text { Kingdom }\end{array}$ & Belgium & Netherlands \\
\hline$r_{-1}$ & $\begin{array}{l}0.589 * * * \\
(2.69)\end{array}$ & $\begin{array}{c}0.038 \\
(0.27)\end{array}$ & $\begin{array}{c}0.056 \\
(0.55)\end{array}$ & $\begin{array}{c}0.292 \\
(0.89)\end{array}$ & $\begin{array}{l}0.370 \\
(1.17)\end{array}$ & $\begin{array}{l}0.939 * * * \\
(2.79)\end{array}$ \\
\hline$\Delta_{4} y$ & $\begin{array}{c}0.062 \\
(0.49)\end{array}$ & $\begin{array}{c}0.186 * \\
(1.75)\end{array}$ & $\begin{array}{c}0.185 \\
(1.32)\end{array}$ & $\begin{array}{l}0.592 * * * \\
(4.29)\end{array}$ & $\begin{array}{l}0.450 \text { *** } \\
(5.18)\end{array}$ & $\begin{array}{c}-0.042 \\
(0.18)\end{array}$ \\
\hline$\triangle_{4} E F P_{-1}$ & $\begin{array}{l}-0.733 * * * \\
(3.04)\end{array}$ & $\begin{array}{c}-0.206 \\
(1.14)\end{array}$ & $\begin{array}{c}0.049 \\
(0.49)\end{array}$ & $\begin{array}{c}-0.435 \\
(1.08)\end{array}$ & $\begin{array}{c}-0.277 \\
(1.25)\end{array}$ & $\begin{array}{r}0.377 \\
(1.59)\end{array}$ \\
\hline $\mathrm{R}^{2}$ & 0.711 & 0.641 & 0.949 & 0.794 & 0.353 & 0.592 \\
\hline $\mathrm{R}^{2}$ (adjusted) & 0.668 & 0.603 & 0.941 & 0.772 & 0.297 & 0.486 \\
\hline SE of regression & 0.014 & 0.007 & 0.006 & 0.013 & 0.017 & 0.013 \\
\hline Wald test, p-value & & & & & & \\
\hline$H_{0}: P I$ model & $0.014 * *$ & 0.196 & 0.211 & $0.000 * * *$ & $0.000 * * *$ & 0.272 \\
\hline$H_{0}: \lambda$-model & $0.004 * * *$ & 0.260 & 0.629 & 0.283 & 0.216 & 0.119 \\
\hline Validity instruments & & & & & & \\
\hline $\mathrm{R}^{2}$ (adjusted) $r_{-1}$ & 0.586 & 0.849 & 0.901 & 0.894 & 0.502 & 0.596 \\
\hline Wald test, $p$-value & $0.000 * * *$ & $0.000 * * *$ & $0.000 * * *$ & $0.000 * * *$ & $0.000 * * *$ & $0.000 * * *$ \\
\hline $\mathrm{R}^{2}$ (adjusted) $\Delta_{4} y$ & 0.622 & 0.602 & 0.905 & 0.740 & 0.493 & 0.739 \\
\hline Wald test, $p$-value & $0.000 * * *$ & $0.000 * * *$ & $0.000 * * *$ & $0.000 * * *$ & $0.000 * * *$ & $0.000 * * *$ \\
\hline $\mathrm{R}^{2}$ (adjusted) $\triangle_{4} E F P_{-1}$ & 0.483 & 0.600 & 0.444 & 0.701 & 0.737 & 0.471 \\
\hline Wald test, $p$-value & $0.000 * * *$ & $0.000 * * *$ & $0.000 * * *$ & $0.000 * * *$ & $0.000 * * *$ & $0.000 * * *$ \\
\hline $\mathrm{R}^{2}$ (adjusted) IV-res & 0.066 & 0.072 & 0.121 & 0.032 & -0.047 & -0.200 \\
\hline Wald test, $p$-value & 0.258 & 0.205 & 0.134 & 0.335 & 0.672 & 0.947 \\
\hline$L M$ test, $p$-value & $0.026 * *$ & $0.078^{*}$ & $0.011 * *$ & 0.138 & 0.370 & 0.173 \\
\hline
\end{tabular}

Explanatory notes: IV estimates of $\Delta_{4} c_{t}=\mu+\left(\lambda_{1}+\lambda_{2}\right) \Delta_{4} y_{t}+0 r_{t-1}+\alpha_{1}{ }^{\prime} \Delta_{4} E F P_{t-1}+\varepsilon_{t}$, based on equation (10) with $\alpha_{2}=0$; see also notes to Table 3 .

The question which arises is why the credit channels are only relevant for Germany. Germany is the classic example of a bank-oriented financial system, but the dependence on finance from financial 
intermediaries in Germany is of the same order as in Italy and the Netherlands and only a little stronger than in the other countries (De Bondt (1998a)). Financial intermediaries account for about 95\% of credit to the private sector in the first group of countries, against $90 \%$ in the other group. An argument is that Germany has the smallest bank concentration of the countries considered. It implies comparatively strong credit market imperfections in Germany, assuming that the degree of asymmetric information between borrowers and lenders and information costs is inversely related to bank size. Although strong banking relationships in Germany (Haus banks) partly offset information asymmetries, these are typically between banks and firms. Moreover, only the three major German banks and some other commercial banks are engaged in relationship banking and they constitute a relatively small part of the banking system.

\subsubsection{Modified $\lambda$-model with financial accelerator effect}

Table 5 summarises the estimation results for the model with a financial propagation mechanism. Again, the real interest rate significantly explains consumption in Germany and the Netherlands. Income significantly explains consumption in all countries excluding Germany and the Netherlands. In Italy, the United Kingdom and Belgium about $50 \%$ of all consumers are liquidity unconstrained, while in the other countries this figure varies between $76 \%$ and $100 \%$. In all cases, the change in the EFP in isolation has no significant impact on consumption growth. However, when combined with the cyclical indicator the impact of the EFP is significant in Germany, Italy and the Netherlands. For these three countries the negative impact of the EFP on consumption is stronger, the deeper the economy is in recession and the modified $\lambda$-model without financial accelerator effect has to be rejected in favour of the consumption model with financial propagation. For the other countries no significant effect is found for the interaction term and the $\lambda$-model is the appropriate consumption model. In all cases except Italy, the statistics indicate that the instruments are valid.

That there is no evidence in favour of the relevance of credit channels on consumption in France, the United Kingdom and Belgium is perhaps due to the fact that disintermediation is more common than in the other countries (De Bondt (1998a)). The significant financial accelerator effect for Germany and Italy supports the findings of Kashyap and Stein (1997) and De Bondt (1998c). Kashyap and Stein review different potential important credit channel variables such as the availability of non-bank finance, the importance of small banks and bank health. Italy appears to be clearly sensitive to the credit channels, while the United Kingdom emerges as the country with potentially weak credit channels. For the other countries the picture is mixed, but Germany and France are close to Italy, while Belgium and the Netherlands are closer to the United Kingdom. De Bondt's (1998c) bank-level panel data study shows empirical evidence in favour of the bank lending channel in continental Europe and of the balance sheet channel in Germany and Italy, suggesting that it is especially the balance sheet channel that enhances the financial propagation mechanism. 
Table 5

Modified $\lambda$-model with financial accelerator effect

\begin{tabular}{|c|c|c|c|c|c|c|}
\hline & Germany & France & Italy & $\begin{array}{c}\text { United } \\
\text { Kingdom }\end{array}$ & Belgium & Netherlands \\
\hline \multirow[t]{2}{*}{$r_{-1}$} & $0.997 * *$ & 0.020 & 0.122 & 0.202 & 0.309 & $0.978 * * *$ \\
\hline & $(2.18)$ & $(0.15)$ & $(1.31)$ & $(0.72)$ & $(0.96)$ & (3.04) \\
\hline \multirow[t]{2}{*}{$\Delta_{4} y$} & 0.153 & $0.244 * *$ & $0.405 * * *$ & $0.546 * * *$ & $0.460 * * *$ & -0.050 \\
\hline & $(1.35)$ & $(2.31)$ & $(2.97)$ & $(4.82)$ & (5.08) & $(0.28)$ \\
\hline \multirow[t]{2}{*}{$\triangle_{4} E F P_{-1}$} & 0.437 & -0.201 & 0.093 & $-0.545^{*}$ & -0.309 & 0.205 \\
\hline & $(0.92)$ & $(1.16)$ & $(0.84)$ & $(1.70)$ & $(1.32)$ & $(0.64)$ \\
\hline \multirow[t]{2}{*}{$\triangle_{4} E F P_{-1} \bullet b c_{-1}$} & $1.307 * *$ & -0.135 & $0.374 * *$ & 0.022 & 0.044 & $0.889 * * *$ \\
\hline & $(2.17)$ & $(0.60)$ & $(2.26)$ & $(0.10)$ & $(0.15)$ & $(2.82)$ \\
\hline $\mathrm{R}^{2}$ & 0.664 & 0.636 & 0.966 & 0.820 & 0.346 & 0.607 \\
\hline $\mathrm{R}^{2}$ (adjusted) & 0.608 & 0.590 & 0.960 & 0.798 & 0.278 & 0.495 \\
\hline SE of regression & 0.015 & 0.007 & 0.005 & 0.012 & 0.018 & 0.013 \\
\hline \multicolumn{7}{|l|}{ Wald test, p-value } \\
\hline$H_{0}: P I$ model & $0.020 * *$ & $0.094 *$ & $0.012 * *$ & $0.000 * * *$ & $0.000 * * *$ & $0.054 *$ \\
\hline$H_{0}: \lambda$-model & $0.099 *$ & 0.450 & $0.088^{*}$ & 0.108 & 0.330 & $0.024 * *$ \\
\hline $\begin{array}{l}H_{0}: \text { mod. } \Lambda \text {-model } \\
\text { without accelerator }\end{array}$ & $0.034 * *$ & 0.553 & $0.028 * *$ & 0.921 & 0.878 & $0.007 * * *$ \\
\hline \multicolumn{7}{|l|}{ Validity instruments } \\
\hline $\mathrm{R}^{2}$ (adjusted) $r_{-1}$ & 0.596 & 0.846 & 0.898 & 0.894 & 0.523 & 0.640 \\
\hline Wald test, $p$-value & $0.000 * * *$ & $0.000 * * *$ & $0.000 * * *$ & $0.000 * * *$ & $0.000 * * *$ & $0.000 * * *$ \\
\hline $\mathrm{R}^{2}$ (adjusted) $\Delta_{4} y$ & 0.636 & 0.662 & 0.908 & 0.740 & 0.485 & 0.732 \\
\hline Wald test, $p$-value & $0.000 * * *$ & $0.000 * * *$ & $0.000 * * *$ & $0.000 * * *$ & $0.000 * * *$ & $0.000 * * *$ \\
\hline $\mathrm{R}^{2}$ (adj.) $\triangle_{4} E F P_{-1}$ & 0.513 & 0.588 & 0.422 & 0.713 & 0.758 & 0.618 \\
\hline Wald test, $p$-value & 0.000 & $0.000 * * *$ & $0.000 * * *$ & $0.000 * * *$ & $0.000 * * *$ & $0.000 * * *$ \\
\hline $\mathrm{R}^{2}(\operatorname{adj}) \Delta_{4} E F P_{-1} \bullet b c_{-1}$ & 0.373 & 0.293 & 0.825 & 0.568 & 0.408 & 0.302 \\
\hline Wald test, $p$-value & $0.001 * * *$ & $0.004 * * *$ & $0.000 * * *$ & $0.000 * * *$ & $0.000 * * *$ & $0.017 * *$ \\
\hline $\mathrm{R}^{2}$ (adjusted) IV-res & -0.146 & 0.064 & 0.338 & 0.087 & -0.072 & -0.295 \\
\hline Wald test, $p$-value & 0.903 & 0.246 & $0.003 * * *$ & 0.187 & 0.755 & 0.999 \\
\hline$L M$ test, $p$-value & 0.309 & $0.073 *$ & $0.000 * * *$ & $0.053 *$ & 0.385 & 0.313 \\
\hline
\end{tabular}

Explanatory notes: IV estimates of $\Delta_{4} c_{t}=\mu+\left(\lambda_{1}+\lambda_{2}\right) \Delta_{4} y_{t}+\theta r_{t-1}+\alpha_{1}{ }^{\prime} \Delta_{4} E F P_{\mathrm{t}-1}+\alpha_{2}{ }^{r} \Delta_{4} E F P_{t-1} \bullet b c_{t-1}+\varepsilon_{t}$, based on equation (10); see also notes to Table 3 .

\subsection{Statistical assessment empirical results}

\subsubsection{Cointegration}

One potential criticism of the consumption models estimated is that according to the cointegration literature the models are specified only in first-differences, the short-term relationships, and ignore completely any cointegration relationship. The implicit restriction of any long-run relationship to be zero, if cointegration does exist, may affect the power of the tests reported. To allow for the possibility of any equilibrium relationship between consumption and income, as introduced in the consumption literature by Davidson et al. (1978) and Davidson and Hendry (1981), the modified $\lambda$-model is respecified including the consumption income ratio lagged four periods. The long-run relationship is 
modelled simultaneously with the short-run adjustment process and the existence of cointegration is directly tested by examining the significance of the coefficient of the error correction term using the critical values as proposed by Kremers et al. (1992) or Boswijk (1994).

Table 6 reports the estimation results of the error correction term. In all cases, the consumption income ratio appears with the expected negative sign, but insignificant. Thus, ignoring a cointegration relationship between consumption and income is statistically appropriate.

Table 6

\section{Cointegration analysis}

\begin{tabular}{l|c|c|c|c|c|c}
\hline & Germany & France & Italy & $\begin{array}{c}\text { United } \\
\text { Kingdom }\end{array}$ & Belgium & Netherlands \\
\hline$(c-y)_{-4}$ & -0.146 & -0.088 & -0.102 & -0.022 & -0.011 & -0.007 \\
& $(0.69)$ & $(0.87)$ & $(0.56)$ & $(0.20$ & $(0.83)$ & $(0.20)$ \\
\hline
\end{tabular}

Explanatory notes: IV estimates of $\Delta 4 c_{t}=\mu+(\lambda 1+\lambda 2) \Delta 4 y_{t}+0 r_{t-1}+\alpha 1^{\prime} \Delta 4 E F P_{t-1}+\alpha 2^{\prime} \Delta 4 E F P_{t-1} \bullet b c_{t-1}+\beta(c-y)-4+\varepsilon_{t}$; see also notes to Table 3.

\subsubsection{Other proxies to capture financial accelerator effect}

To further evaluate the modified $\lambda$-model we perform specification tests by incorporating the financial propagation mechanism in a different way. From a statistical point of view one may be suspicious that the results in Table 5 are driven by not taking into account the business cycle as a separate explanatory variable. In a theoretical context the business cycle fits in the modified $\lambda$-model under the assumption that the supply of external finance for consumption expenditure also depends on the business cycle. If we add $b c_{t-1}$ as explanatory variable in equation (9) gives

$$
\Delta \text { credit supply } y_{t}=\alpha_{0}+\alpha_{1} \Delta E F P_{t-1}+\alpha_{2} \Delta E F P_{t-1} \bullet b c_{t-1}+\alpha_{3} b c_{t-1}
$$

where $\alpha_{3}$ reflects the willingness of banks to lend for consumption expenditure. The willingness to lend is expected to depend positively on the business cycle. Another economic interpretation of the inclusion of the business cycle is that the willingness of consumers to consume is positively related to the business cycle. In this way, the separate business cycle term reflects the "state of confidence" in the economy, as mentioned by Keynes. Two basic determinants of this state can be distinguished. The first is the "state of credit", which is governed by the confidence that lenders have in financing consumption expenditure (willingness to lend). The second is consumers' belief about prospective yields from financial and labour income (willingness to consume). Another argument, related to the last one, is precautionary saving. Households save more and consume less during recessions. ${ }^{7}$

7 For the same reason money demand studies include a cyclical indicator, capturing speculation and precautionary motives (Fase (1998)). 
Table 7 presents the estimation results of this modified $\lambda$-model with financial accelerator effect and "state of confidence". ${ }^{8}$ For France, the United Kingdom and Belgium the impact of the change in the EFP and for the other countries the effect of the interaction term between the EFP and the business cycle become statistically more significant by taking the "state of confidence" into account. The EFP now explains significantly British and Belgian consumption with a level of $1 \%$. In both Italy and the Netherlands, the financial accelerator effect is now significant at the $1 \%$ level. In all cases, the cyclical indicator has a positive impact on consumption and is especially relevant in the United Kingdom, Belgium and the Netherlands.

Table 7

Modified $\lambda$-model with financial accelerator effect and "state of confidence"

\begin{tabular}{|c|c|c|c|c|c|c|}
\hline & Germany & France & Italy & $\begin{array}{c}\text { United } \\
\text { Kingdom }\end{array}$ & Belgium & Netherlands \\
\hline \multirow[t]{2}{*}{$r_{-1}$} & $0.957 * *$ & 0.071 & 0.115 & -0.176 & 0.390 & $0.753^{* * * *}$ \\
\hline & $(2.07)$ & $(0.67)$ & $(1.15)$ & $(0.69)$ & $(1.22)$ & (2.81) \\
\hline \multirow[t]{2}{*}{$\Delta_{4} y$} & 0.158 & $0.201^{* *}$ & $0.516^{* * *}$ & $0.369^{* *}$ & $0.268^{* * *}$ & 0.163 \\
\hline & $(1.38)$ & $(2.32)$ & (3.43) & $(2.03)$ & $(3.24)$ & $(1.58)$ \\
\hline \multirow{2}{*}{$\triangle_{4} E F P_{-1}$} & 0.295 & -0.255 & 0.104 & $-1.280 * * *$ & $-0.667 * * *$ & -0.136 \\
\hline & $(0.69)$ & $(1.58)$ & (1.07) & $(4.84)$ & $(2.95)$ & $(0.62)$ \\
\hline \multirow[t]{2}{*}{$\Delta_{4} E F P_{-1} \bullet b c_{-1}$} & $1.288^{* *}$ & -0.335 & $0.370 * * *$ & -0.129 & -0.257 & $0.850^{* * *}$ \\
\hline & $(2.36)$ & $(1.34)$ & (2.82) & $(0.88)$ & $(1.15)$ & $(4.29)$ \\
\hline \multirow[t]{2}{*}{$b c_{-1}$} & 0.001 & 0.001 & 0.003 & 0.010 & $0.015^{* * *}$ & $0.006^{*}$ \\
\hline & $(0.46)$ & $(0.21)$ & $(0.84)$ & $(1.65)$ & (3.99) & (1.97) \\
\hline $\mathrm{R}^{2}$ & 0.672 & 0.596 & 0.972 & 0.823 & 0.525 & 0.717 \\
\hline $\mathrm{R}^{2}$ (adjusted) & 0.610 & 0.537 & 0.966 & 0.797 & 0.466 & 0.629 \\
\hline SE of regression & 0.015 & 0.008 & 0.004 & 0.012 & 0.015 & 0.011 \\
\hline \multicolumn{7}{|l|}{ Wald test, p-value } \\
\hline$H_{0}: P I$ model & $0.006 * * *$ & $0.019^{* *}$ & $0.000 * * *$ & $0.000 * * *$ & $0.000 * * *$ & $0.001^{* * * *}$ \\
\hline$H_{0}: \lambda$-model & $0.093^{*}$ & 0.402 & $0.030^{* *}$ & $0.000^{* * * *}$ & $0.003^{* * * *}$ & $0.001^{* * * *}$ \\
\hline $\begin{array}{l}H_{0}: \text { mod. } \lambda \text {-model } \\
\text { without accelerator }\end{array}$ & $0.054 *$ & 0.403 & $0.015^{* *}$ & 0.242 & $0.001 * * *$ & $0.000^{* * * *}$ \\
\hline
\end{tabular}

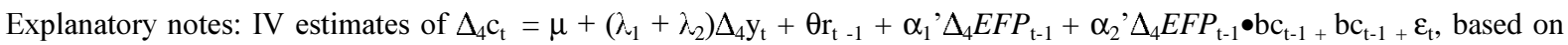
equation (8) and equation(11); see also notes to Table 3.

Another way to incorporate the financial propagation mechanism in the modified $\lambda$-model is to look explicitly at periods of weak economic activity, replacing equation (9) by

$$
\Delta \text { credit supply } y_{t}=\alpha_{0}+\alpha_{1} \Delta E F P_{t-1}+\alpha_{2} \Delta E F P_{t-1} \bullet d u m b c_{t-1}
$$

where $d u m b c$ is a dummy variable which has the value 1 as the business cycle is below its trend value and 0 otherwise. On the one hand, this way of incorporating the credit channels of monetary policy stresses the asymmetric nature of the financial propagation mechanism (Bernanke and Gertler (1989)

8 The statistics with respect to the validity of the instruments are not reported in order to save space, but are available on request. The same holds for Table 8 . 
and De Bondt (1998b)). On the other, the dummy variable implies an arbitrary choice of when the financial accelerator effect is effective.

Table 8 shows the estimation results of this version of the modified $\lambda$-model. Again, for the same three countries the financial accelerator effect is evident. The impact of the EFP on consumption during periods of a cyclical position below trend is negative, while it is otherwise positive. Last effect is especially large in Germany and the Netherlands. When economic activity is above trend, an increase of the average $E F P$ for consumers may imply that banks tend to lend to more risky borrowers leading to an increase in consumption. For Germany and the Netherlands the hypothesis that the impact of the EFP equals that of the impact during periods when the business cycle is below trend value is rejected at the $10 \%$ significance level (see Wald test $\alpha_{1}{ }^{\prime}=\alpha_{2}{ }^{\prime}$ ). For France, the United Kingdom and Belgium the coefficient with respect to the EFP is about -0.45 , though not significant.

Table 8

Modified $\lambda$-model with financial accelerator effect captured by cyclical indicator below trend value

\begin{tabular}{l|c|c|c|c|c|c}
\hline & Germany & France & Italy & $\begin{array}{c}\text { United } \\
\text { Kingdom }\end{array}$ & Belgium & Netherlands \\
\hline$r_{-1}$ & $0.677^{* * *}$ & 0.015 & 0.003 & 0.170 & 0.349 & $0.906^{* * *}$ \\
& $(2.84)$ & $(0.12)$ & $(0.02)$ & $(0.51)$ & $(1.12)$ & $(2.69)$ \\
$\Lambda_{4} y$ & 0.185 & $0.257^{* *}$ & $0.277^{* *}$ & $0.526^{* * *}$ & $0.461^{* * *}$ & -0.155 \\
& $(1.43)$ & $(2.31)$ & $(2.57)$ & $(4.19)$ & $(5.16)$ & $(1.81)$ \\
$\triangle_{4} E F P_{-1}$ & 0.761 & -0.475 & 0.135 & -0.448 & -0.438 & $0.805^{*}$ \\
& $(1.32)$ & $(1.49)$ & $(0.67)$ & $(0.88)$ & $(1.22)$ & $(1.80)$ \\
$\Lambda_{4} E F P_{-1} \bullet$ dumbc-1 & $-1.386^{* *}$ & 0.301 & -0.194 & -0.355 & 0.268 & $-1.082^{*}$ \\
$\mathrm{R}^{2}$ & $(1.98)$ & $(0.63)$ & $(0.80)$ & $(1.12)$ & $(0.55)$ & $(1.66)$ \\
$\mathrm{R}^{2}$ (adjusted) & 0.695 & 0.590 & 0.955 & 0.811 & 0.338 & 0.588 \\
$\mathrm{SE}$ of regression & 0.644 & 0.539 & 0.947 & 0.788 & 0.268 & 0.471 \\
$\mathrm{Wald}_{\text {ald test, p-value }}$ & 0.015 & 0.008 & 0.005 & 0.013 & 0.018 & 0.013 \\
$H_{0}: P I$ model & & & & & & \\
$H_{0}: \lambda$-model & $0.039^{* *}$ & 0.107 & $0.050^{* *}$ & $0.000^{* * *}$ & $0.000^{* * *}$ & 0.338 \\
$H_{0}:$ mod. $\lambda$-model & 0.129 & 0.236 & 0.714 & $0.014 * *$ & 0.385 & 0.186 \\
without accelerator & $0.053^{*}$ & 0.529 & 0.429 & 0.269 & 0.584 & $0.096^{*}$ \\
$H_{0:} \alpha_{1}^{\prime}=\alpha_{2}^{\prime}$ & & & & & & \\
\hline & $0.084^{*}$ & 0.307 & 0.456 & 0.906 & 0.380 & $0.071^{*}$ \\
\hline
\end{tabular}

Explanatory notes: IV estimates of $\Delta_{4} c_{t}=\mu+\left(\lambda_{1}+\lambda_{2}\right) \Delta_{4} y_{t}+\theta r_{t-1}+\alpha_{1}{ }^{\prime} \Delta_{4} E F P_{t-1}+\alpha_{2}{ }^{\prime} \Delta_{4} E F P_{t-1} \bullet d u m b c_{t-1}+\varepsilon_{t}$, based on equation (8) and equation (12); see also notes to Table 3.

\subsection{Economic assessment empirical results}

\subsubsection{Intertemporal elasticity of substitution}

The first economic assessment of the empirical results focuses on the real interest rate sensitivity of consumption. Table 9 summarises the implied intertemporal elasticities of substitution, $\sigma$, according to 
the different consumption models. The table shows substantial cross-country differences in the degree of the sensitivity of consumption to the real interest rate. A $1 \%$ rise in the real interest rate lowers current consumption by at most $0.2 \%$ in France and Italy, about $0.5 \%$ in the United Kingdom and Belgium, and around $0.9 \%$ in Germany and the Netherlands.

Table 9

Implied intertemporal elasticity of substitution

\begin{tabular}{l|c|c|c|c|c|c}
\hline & Germany & France & Italy & $\begin{array}{c}\text { United } \\
\text { Kingdom }\end{array}$ & Belgium & Netherlands \\
\hline$\lambda$-model & 0.376 & 0.025 & -0.016 & 0.217 & 0.773 & 1.035 \\
$\begin{array}{l}\text { Accelerator effect } \\
\text { modified } \lambda \text {-model }\end{array}$ & & & & & & \\
No & 0.628 & 0.046 & 0.068 & 0.716 & 0.673 & 0.901 \\
$\triangle_{4} E F P \bullet b c$ & 1.177 & 0.026 & 0.205 & 0.445 & 0.573 & 0.931 \\
$\triangle_{4} E F P \bullet b c+b c$ & 1.136 & 0.090 & 0.237 & -0.279 & 0.533 & 0.899 \\
$\triangle_{4} E F P \bullet d u m b c$ & 0.831 & 0.020 & 0.005 & 0.359 & 0.648 & 0.784 \\
Mean $*$ & & & & & & \\
All models & 0.760 & 0.050 & 0.103 & 0.347 & 0.734 & 0.927 \\
Modified $\lambda$-models & 0.943 & 0.046 & 0.129 & 0.380 & 0.607 & 0.879 \\
\hline
\end{tabular}

Explanatory notes: implied $\sigma$ computed as estimated 0 multiplied by estimated fraction of liquidity-unconstrained consumers, as reported in Table 3, 4, 5, 7 and 8 respectively.

* Negative numbers are set to zero.

For the United Kingdom the elasticities are close to the values of 0.2 and 0.4, as reported by Sarno and Taylor (1998) and Bayoumi (1993), respectively. Other studies, examining only nondurable consumption, broadly speaking do not find significant real interest rate effect, perhaps because nondurable consumption is less sensitive to monetary policy shocks than the consumption of durable goods as shown by Bernanke and Gertler (1995). Moreover, the strong interest rate effects can be due to the sample period, which is characterised as a period of financial deregulation (Muellbauer and Lattimore (1995)). This may also explain the low interest rate sensitivity of French and Italian consumption, since these two countries were still comparatively highly financially regulated in the 1980s (De Bondt (1998a)).

\subsubsection{Financial accelerator effect}

The second and last economic evaluation concerns the potential impact of the financial accelerator effect on consumption by focusing on an episode where the interaction between the EFP and the cyclical indicator reaches its absolute minimum, because credit market imperfections matter most in severe recessions. The minimum occurs in one of the quarters of 1981 (see Table 10). The highest nearby value of the interaction term occurs around one and half years earlier. The cumulative and average decline in consumption during this episode due to the financial accelerator effect is presented in Table 10. 
Table 10

Impact financial accelerator effect

\begin{tabular}{l|c|c|c|c|c|c}
\hline & Germany & France & Italy & $\begin{array}{c}\text { United } \\
\text { Kingdom }\end{array}$ & Belgium & Netherlands \\
\hline Maximum early 1980s & $1979: 4$ & $1980: 2$ & $1980: 2$ & $1980: 2$ & $1980: 3$ & $1980: 3$ \\
Absolute minimum & $1981: 4$ & $1981: 4$ & $1981: 3$ & $1981: 1$ & $1981: 2$ & $1981: 4$ \\
$\begin{array}{l}\text { Number of quarters } \\
\text { Change in \% }\end{array}$ & 9 & 7 & 6 & 4 & 4 & 6 \\
consumption & & & & & & \\
Cumulative & -3.99 & 0.52 & -2.08 & -0.27 & -0.30 & -2.76 \\
Average per quarter & -0.44 & 0.07 & -0.35 & -0.07 & -0.07 & -0.46 \\
\hline
\end{tabular}

Explanatory notes: impact based on estimates reported in Table 5.

For France, the United Kingdom and Belgium, the impact of the financial accelerator effect is small. For the other countries the cumulative impact on consumption during this episode varies between $-2.1 \%$ in Italy to $-4 \%$ in Germany. Assuming that this decline is evenly distributed over the quarters involved, it implies that annual consumption growth can decline due to the financial accelerator effect with about 0.4 percentage point on average per quarter in Germany, Italy and the Netherlands.

\section{Concluding remarks}

For the monetary authorities perhaps the most relevant conclusion - besides more general insights in consumption behaviour in Europe - is that this study supports the view that credit channels of monetary policy are a macroeconomic relevant financial propagation mechanism. The degree of relevance, however, differs between the European countries considered. The empirical results show a significant accelerator effect of the EFP on total private consumption for Germany, Italy and the Netherlands. In recessions this financial accelerator effect may lead to a decline in annual consumption growth by about 0.4 percentage point per quarter. In contrast, for France, the United Kingdom and Belgium no significant financial propagation mechanism has been found.

Another implication for monetary policy, especially within EMU context, is the cross-country difference regarding the intertemporal elasticity of substitution. Consumption is comparatively insensitive to movements in the real interest rate in France and Italy, probably because both countries were subject to relatively high financial regulation in a part of the sample period. If this is the case, it illustrates that financial liberalisation increases the interest rate sensitivity of consumption. The estimation results show that an increase in the real interest rate with 1 percentage point leads to a decline in current real per capita consumption of at most $0.2 \%$ in France and Italy, around $0.5 \%$ in the United Kingdom and Belgium and about $0.9 \%$ in Germany and the Netherlands. 


\section{References}

Antzoulatos, A A (1994): "Borrowing Constraints, Income Expectations and the Euler Equation: Theory and Evidence". Economics Letters, 45, 3, pp. 323-27.

Antzoulatos, A A (1996): "Consumer Credit and Consumption Forecasts". International Journal of Forecasting, 12, pp. 439-53.

Antzoulatos, A A (1997): "On the Excess Sensitivity of Consumption to Information About Income". Journal of Macroeconomics, 19, 3, pp. 539-53.

Bacchetta, P and S Gerlach (1997): "Consumption and Credit Constraints: Some International Evidence". Journal of Monetary Economics, 40, pp. 207-38.

Bárran, F (1996): Monetary Policy and Credit Constraints, Phd, Université Catholique de Louvain.

Bayoumi, T (1993): "Financial Deregulation and Consumption in the United Kingdom". Review of Economics and Statistics, 75, pp. 536-9.

Berk, J M and J A Bikker (1995): "International Dependence of Business Cycles in the Manufacturing Industry: the Use of Leading Indicators for Forecasting and Analysis". Journal of Forecasting, 14, 1, pp. 1-23.

Bernanke, B S and M Gertler (1989): "Agency Costs, Net Worth, and Business Fluctuations". American Economic Review, 79, pp. 14-31.

Bernanke, B S and M Gertler (1995): "Inside the Black Box: the Credit Channel of Monetary Policy Transmission”. Journal of Economic Perspectives, 9, 1, pp. 27-48.

Bikker, J A and L de Haan (1988): "Forecasting Business Cycles: a Leading Indicator for the Netherlands". Quarterly Bulletin, 3, De Nederlandsche Bank, pp. 71-82.

Blundell-Wignall, A, F Browne and A Tarditi (1995): "Financial Liberalization and the Permanent Income Hypothesis". The Manchester School, 63, 2, pp. 125-44.

Bondt, G J de (1998a): "Financial Structure: Theories and Stylized Facts For Six EU Countries". De Economist, 146, 2, pp. 271-301.

Bondt, G J de (1998b): "Credit and Asymmetric Effects of Monetary Policy in Six EU Countries: an Overview". DNB Staff Reports, 23, De Nederlandsche Bank.

Bondt, G J de (1998c): "Credit Channels in Europe: Bank-Level Panel Data Analyses". Research Memorandum WO\&E, 543, June, De Nederlandsche Bank.

Bondt, G J de, P J A van Els and A C J Stokman (1997): "EUROMON: a Macroeconometric MultiCountry Model for the EU”. DNB Staff Reports, 17, De Nederlandsche Bank.

Boswijk, H P (1994): "Testing for an Unstable Root in Conditional and Structural Error Correction Models". Journal of Econometrics, 63, pp. 37-60.

Campbell, J Y and N G Mankiw (1990): "Permanent Income, Current Income and Consumption". Journal of Business and Economic Statistics, 8, pp. 265-79.

Campbell, J Y and N G Mankiw (1991): "The Response of Consumption to Income: a Cross-Country Investigation”. European Economic Review, 35, pp. 715-21.

Cochrane, J H (1989): "The Sensitivity of Tests of the Intertemporal Allocation of Consumption to Near-Rational Alternatives". American Economic Review, 79, pp. 319-37.

Davidson, JEH and D F Hendry (1981): “Interpreting Econometric Evidence: Consumers' Expenditures". European Economic Review, 16, pp. 177-92.

Davidson, J E H, D F Hendry, F Srba and S Yeo (1978): "Econometric Modelling of the Aggregate Time-Series Relationship Between Consumers' Expenditure and Income in the United Kingdom". Economic Journal, 88, pp. 661-92. 
Davis, E P and S G B Henry (1994): "The Use of Financial Spreads as Indicator Variables: Evidence for the UK and Germany". IMF Working Paper, 31, March, International Monetary Fund.

Dimsdale, N (1994): "Banks, Capital Markets, and the Monetary Transmission Mechanism". Oxford Review of Economic Policy, 10, 4, pp. 34-48.

Fase, M M G (1995): “The Demand for Commercial Bank Loans and the Lending Rate". European Economic Review, 39, pp. 99-111.

Fase, M M G (1998): On Money and Credit in Europe. The Selected Essays of Martin M.G. Fase, Edward Elgar, Cheltenham/Northampton.

Fase, M M G and J A Bikker (1985): "De datering van Economische Fluctuaties; Proeve van een Conjunctuurspiegel Voor Nederland 1965-1984" (The dating of Economic Fluctuations; Testing a Business Cycle Indicator for the Netherlands). Maandschrift Economie, 49, pp. 299-332.

Gertler, M and S Gilchrist (1993): "The Role of Credit Market Imperfections in the Monetary Transmission Mechanism: Arguments and Evidence". Scandinavian Journal of Economics, 95, 1, pp. 43-64.

Hall, R E (1978): "Stochastic Implications of the Life Cycle-Permanent Income Hypothesis: Theory and Evidence". Journal of Political Economy, 86, pp. 971-87.

Jappelli, T and M Pagano (1989): "Consumption and Capital Market Imperfections: an International Comparison". American Economic Review, 79, pp. 1088-105.

Kashyap, A K and J C Stein (1997): "The Role of Banks in Monetary Policy: a Survey With Implications for the European Monetary Union”. Economic Perspectives, 21, Federal Reserve Bank of Chicago, pp. 2-19.

King, M A (1986): "Capital Market 'Imperfections' and the Consumption Function”. Scandinavian Journal of Economics, 88, pp. 59-80.

Kremers, J J M, N R Ericsson and J J Dolado (1992), "The Power of Cointegration tests". Oxford Bulletin of Economics and Statistics, 54, 3, pp. 325-48.

Kroes, T (1996): Financial Intermediation and Monetary Transmission, Phd, University of Amsterdam, Amsterdam.

Mankiw, N G (1982): "Hall's Consumption Hypothesis and Durable Goods". Journal of Monetary Economics, 10, pp. 417-26.

Muellbauer, J and R Lattimore (1995): "The Consumption Function: a Theoretical and Empirical Overview", in: Handbook of Applied Econometrics: Macroeconomics, H Pesaran and M Wickens (eds), Blackwell Publishers, pp. 221-311.

Ramey, V (1993): "How Important is the Credit Channel in the Transmission of Monetary Policy?" Carnegie-Rochester Conference Series on Public Policy, 39, pp. 1-45.

Sarno, L and M P Taylor (1998): "Real Interest Rates, Liquidity Constraints and Financial Deregulation: Private Consumption Behavior in the UK". Journal of Macroeconomics, 20, 2, pp. 221-42.

Shea, J (1995): "Myopia, Liquidity Constraints, and Aggregate Consumption: a Simple Test". Journal of Money, Credit, and Banking, 27, 3, pp. 798-805.

Tsatsaronis, K (1995): "Is There a Credit Channel in the Transmission of Monetary Policy? Evidence From Four Countries", in: BIS, Financial Structure and the Monetary Policy Transmission Mechanism. CB Document, 394, March, pp. 154-87.

Vrolijk, C (1997): "Derivatives Effect on Monetary Policy Transmission". IMF Working Paper, 121, September, International Monetary Fund.

Winder, C C A and F C Palm (1989): "Intertemporal Consumer Behaviour Under Structural Changes in Income". Econometric Reviews, 8, 1, pp. 1-87. 


\section{Recent BIS Working Papers}

No.

53

March 1998

54

June 1998

55

June 1998

56

June 1998

57

July 1998

58

November 1998

59

November 1998

60

November 1998

61

November 1998

62

March 1999

63

March 1999

64

March 1999

65

April 1999

66

April 1999

67

May 1999

68

May 1999
Title

Exchange rate regimes and inflation and output in Sub-Saharan countries

The coming transformation of continental European banking?

Spread overreaction in international bond markets

Commercial banks in the securities business: a review

One-step prediction of financial time-series

The importance of bank seniority for relationship lending

Portfolio selection using fuzzy decision theory

Output gap uncertainty: does it matter for the Taylor rule?

Foreign direct investment and employment in the industrial countries

The pricing of bank lending and borrowing: evidence from the federal funds market

Microeconomic inventory adjustment and aggregate dynamics

Precarious credit equilibria: reflections on the Asian financial crisis

Higher profits and lower capital prices: is factor allocation optimal?

Evolving international financial markets: some implications for central banks

The cyclical sensitivity of seasonality in US employment

The evolution and determinants of emerging market credit spreads in the $1990 \mathrm{~s}$
Author

Marc Klau

William R White

Gregory D Sutton

João A C Santos

Srichander

Ramaswamy

Stanley D Longhofer and João A C Santos

Srichander

Ramaswamy

Frank Smets

P S Andersen and $\mathrm{P}$ Hainaut

Craig H Furfine

Jonathan McCarthy and Egon Zakrajšek

Joseph Bisignano

P S Andersen, M Klau and $\mathrm{E}$ Yndgaard

William R White

Spencer Krane and William Wascher

Steven B Kamin and Karsten von Kleist 
ISSN 1020-0959 